\title{
Antioxidant Activity of gossypitrin isolated from the petals of Talipariti elatum (Sw.) Fryxell (Malvaceae) in Cuba
}

\author{
José González ${ }^{1 *}$, Armando Cuéllar ${ }^{2}$, Pedro Abreu ${ }^{3}$, Max Monan ${ }^{4}$, Enmanuel Nossin ${ }^{5}$, \\ Frantz François-Haugrin ${ }^{6}$
}

${ }^{1}$ Department of Pharmacy, Faculty of Pharmacy and Foods, Cuba.

${ }^{2}$ REQUIMTE, Departamento de Química, Faculdade de Ciências e Tecnologia da Universidade Nova de Lisboa, 2829-

516 Caparica, Portugal.

${ }^{3}$ ARVARNAM, Martinica.

\begin{abstract}
Talipariti elatum Sw. Fryxell (Malvaceae) is an endemic tree widely distributed in Cuba. The flowers are used in traditional medicine for the treatment of asthma. It was decided to search for any product responsible of this devoted activity. From the flower leaves (petals) it was isolated a flavonoid glycoside characterized as Gossypitrin and a sample was evaluated for its in vitro scavenging effects on reactive oxygen species (ROS) $\left(\mathrm{O}, \mathrm{HO}, \mathrm{HOCl}, \mathrm{ROO}\right.$, and $\left.\mathrm{H}_{2} \mathrm{O}_{2}\right)$, reactive nitrogen species (RNS) (ONOO and NO) and $\mathrm{ABTS}^{\circ}$, DPPH radicals and Reducing Power assay. Additionally, two enzymatic assays (Inhibition of xanthine oxidase $(\mathrm{XO})$ and Effect on $\mathrm{XO}$ activity) were also evaluated. In the scavenging assays the sample showed to be not effective against all assayed ROS and RNS, and displayed a weak activity in the $D P P H$ and Reducing Power assays, but it displayed a good activity in the ABTS ${ }^{++}$assay $(2,14 \mathrm{mM})$. The enzymatic assays corroborated that Gossypitrin shows a weak activity on inhibition of XO. These results provide scientific support for the empirical use of the flowers of $T$. elatum as an antasthmatic medicine.
\end{abstract}

Keywords - Talipariti elatum, scavenging effect, reactive oxygen species, reactive nitrogen species, antioxidant activity.

\section{INTRODUCTION}

Flavonoids are among the most ubiquitous groups of plant secondary metabolites distributed in various foods and medicinal plants. They are largely planar molecules and their structural variation comes in part from the pattern of substitution: hydroxylation, methoxylation, prenylation, or glycosylation. Although they are sometimes found as their aglycones, flavonoid most commonly occur in plant materials as flavonoid $O$-glycosides, in which one or more hydroxyl groups of the aglycones are bound to a sugar, forming an acid-labile glycosidic O-C bond. There are certain hydroxyl groups in flavonoids that are usually glycosylated. These are the 7-hydroxyl group in flavones, flavanones, and isoflavones and the 3- and 7-hydroxyl groups in flavonols and flavanols. 5-O-Glycosides are rare for compounds with a carbonyl group at C-4, since the 5-hydroxyl group participates in hydrogen bonding with the adjacent carbonyl at C-4 (Larson, 1997). These polyphenols show biological properties through their free-radical-scavenging antioxidant activities and metal-ion chelating abilities. They are also known for their ability to inhibit enzymes such as protein kinase C, several protein-tyrosine kinases, or cyclic-dependent kinases (Akiyama et al., 1987; Wang et al., 2003; Frey et al., 2003) Flavonoids are converted to several other phenolic acids. Some of these metabolites have shown higher antioxidative and estrogenic activities (measured in vitro) than their parent compounds, for instance equal compared with daidzein (Rimbach et al., 2003).

Most interest has been focused on the antioxidant activity of flavonoids, which is due to their ability to reduce free radical formation and to scavenge free radicals. To establish the role of flavonoids as antioxidant in vivo, it is critical to understand the chemical nature of the absorbed forms in the circulation in vivo. The antioxidant efficacy of flavonoids in vivo is poorly documented, presumably because of the limited knowledge on their uptake and distribution in humans. Most ingested flavonoids are extensively degraded to various phenolic acids, some of which still possess a radical-scavenging ability (Rowland et al., 2003).

Gossypitrin is a flavonoid isolated and characterized from the flower leaves (petals) of Talipariti elatum Sw. Fryxell (Malvaceae), a tree with a wide distribution in Cuba, that growth in any type of soil, particularly in swanpyones. It can get about $25 \mathrm{~m}$ of height. It shows peciolated leaves, to mentose-velvet like and heart-shaped at the basis. The flowers are big, yellow flower leaves that become reddish when old. The flowers are used as appetitive, emollient, sudorific and as excellent expectorant combined with the flowers of Hibiscus rosa-sinensis. The mixture is used in traditional medicine as expectorant and antasthmatic (Roig, 1974: Acosta y Rodríguez, 2006). The aim of the present study was to evaluate the 
in vitro scavenging effects of a sample of gossypitrin on $\mathrm{ROS}\left(\mathrm{O}^{-}, \mathrm{HO}, \mathrm{HOCl}, \mathrm{ROO}\right.$, and $\left.\mathrm{H} 2 \mathrm{O} 2\right), \mathrm{RNS}^{\circ} \mathrm{ONOO}^{-}$and $\left.\mathrm{NO}\right)$ and DPPH radical

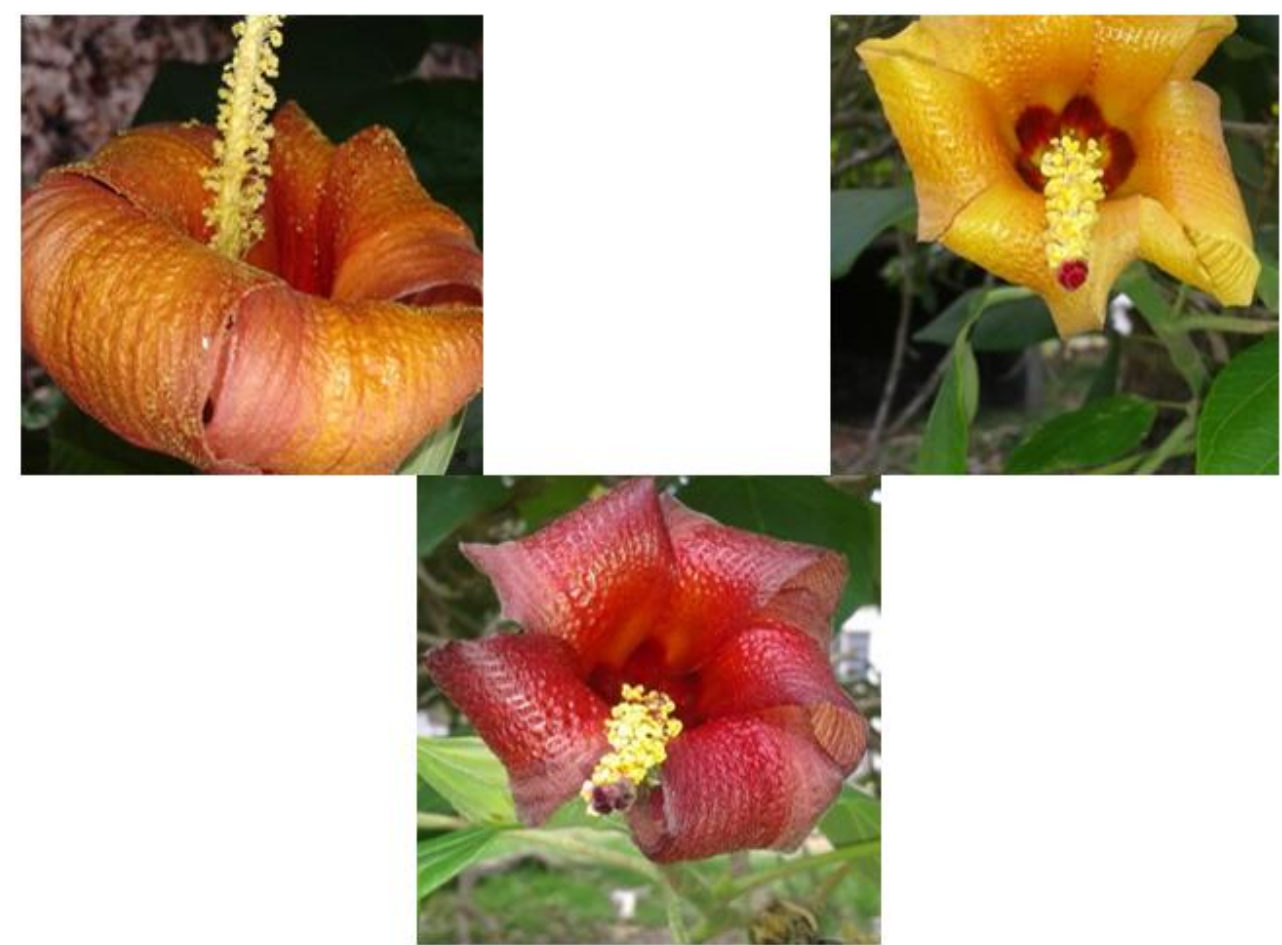

FIGURE 1. FLOWERS OF T. ELATUM SW

\section{MATERIAL AND METHODS}

\subsection{DPPH assay}

DPPH scavenging activity was measured according to the procedure described by Blois (Blois, 1958). Briefly, each test sample $(100 \mathrm{~mL})$ of various concentrations $(0.015-0.500 \mathrm{mg} / \mathrm{mL})$ was added to $900 \mathrm{~mL}$ of freshly prepared DPPH solution $(0.004 \%$ in $\mathrm{MeOH})$, and the mixture vortexed for $15 \mathrm{~s}$. The decrease in absorbance at room temperature was determined at $515 \mathrm{~nm}$ after 30-45 min of incubation. All experiments were performed in triplicate. The inhibition percentage $(\%)$ of radical scavenging activity was calculated as $\left(1-\mathrm{A}_{\mathrm{s}} / \mathrm{A}_{0}\right) \times 100$, where $\mathrm{A}_{0}$ and $\mathrm{A}_{\mathrm{s}}$ are the absorbance of the control and sample, respectively, at $515 \mathrm{~nm}$. $\alpha$-tocopherol and quercetin were used as standards.

\subsection{Radical Cation ABTS•+ scavenging activity}

The radical cation $\mathrm{ABTS}^{++}$scavenging activity was evaluated according to the modified TEAC method of Re et al., 1999. $\operatorname{ABTS}^{\circ+}(7 \mathrm{mM})$ was dissolved in milli $\mathrm{Q}$ water and added topotassium persulfate to reach a $2.4 \mathrm{mM}$ final concentration. The reaction mixture was left $16 \mathrm{~h}$ in dark at room temperature, and the radical cation solution was further diluted with water to give an absorbance value of $0.700 \pm 0.03$ at $734 \mathrm{~nm}$. Samples were diluted with $\mathrm{H}_{2} \mathrm{O} / \mathrm{EtOH}$ so that after the addition of $15 \mathrm{~mL}$ to $1.485 \mathrm{~mL}$ of $\mathrm{ABTS}^{\circ+}$, a $20 \%-80 \%$ decrease in the initial absorbance at $734 \mathrm{~nm}$ is observed. The decrease of absorbance was recorded at time intervals of $1,2,5,10$ and $15 \mathrm{~min}$, for a range of 5-8 concentrations ( 0 to $20 \mathrm{mM}$ final concentration after addition of $\mathrm{ABTS}^{++}$) for each sample. Assays were performed in triplicate and solvent blanks were run in each assay. The percentage inhibition of absorbance at $734 \mathrm{~nm}$ was calculated and plotted as a function of sample concentration and that of the antioxidant standard Trolox (6-hydroxy-2,5,7,8-tetramethylchroman-2-carboxylic acid). The scavenging activity is estimated within the range of the dose-response curve of Trolox and expressed as the Trolox equivalent antioxidant capacity (TEAC), which is defined as the concentration (mM) of Trolox having the equivalent antioxidant capacity to a $1.0 \mathrm{mM}$ or $1 \mathrm{mg} / \mathrm{mL}$ of the tested sample solution.

\subsection{Reducing Power assay}

Reducing power was determined according to the method of Oyaizu (Oyaizu, 1986). Samples (0.02-1.0 mg) were dissolved in $1.0 \mathrm{~mL}$ of milli Q water to which was added $2.5 \mathrm{~mL}$ of a $0.2 \mathrm{mM}$ phosphate buffer $(\mathrm{pH} 6.6)$ and $2.5 \mathrm{~mL}$ of a $1 \%(\mathrm{w} / \mathrm{v})$ solution of potassium ferricyanide. The mixture was incubated in a water bath for $20 \mathrm{~min}$ at $50{ }^{\circ} \mathrm{C}$, followed by the 
addition of $2.5 \mathrm{~mL}$ of a $10 \%(\mathrm{w} / \mathrm{v})$ trichloroacetic acid solution. The mixture was then centrifuged at $5000 \mathrm{rpm}$ for $10 \mathrm{~min}$, and a $2.5 \mathrm{~mL}$ aliquot of the resulting upper layer was combined with $2.5 \mathrm{~mL}$ of Milli Q water and $0.5 \mathrm{~mL}$ of a $0.1 \%(\mathrm{w} / \mathrm{v}$ ) $\mathrm{FeCl}_{3}$ solution. The absorbance of the reaction mixture was read spectrophotometrically at $700 \mathrm{~nm}$ against a blank sample. The mean absorbances from three independent samples were plotted against concentration and a linear regression analysis was carried out to calculate the $\mathrm{IC}_{50}$ value, defined as the effective concentration at which the decrease in absorbance was 0.50 at $700 \mathrm{~nm}$. $\alpha$-tocopherol and quercetin were used as standards.

\subsection{Assessment of scavenging activity against reactive oxygen species (ROS) and reactive nitrogen species (RNS)}

For assessment of scavenging activity against ROS and RNS, the sample is dissolved in the buffer solution applied in each assay in order to achieve concentration values up to $10 \mathrm{mg}$ of dried solid/mL. All determinations were performed in a microplate reader (Synergy HT, BIO-TEK), using spectrometric, fluorimetric or chemiluminiscence detection. Each study corresponds to four experiments performed in triplicate at $37^{\circ} \mathrm{C}$.

\subsubsection{Superoxide radical $\left(\mathrm{O}^{-}\right)$scavenging assay}

The $\mathrm{O}_{2}{ }^{-}$scavenging activity was measured by monitoring the $\mathrm{O}_{2}{ }^{-}$induced reduction of nitroblue tetrazolium chloride (NBT) to the blue chromogen diformazan (Fernandes et al., 2003). $\mathrm{O}_{2}{ }^{-}$were generated by the phenazine methosulphate (PMS)/NADH system. The reaction mixtures in the sample wells contained, in a final volume of $300 \mu \mathrm{L}$, the following reagents at the indicates final concentrations: NBT $(43 \mu \mathrm{M})$, NADH $(166 \mu \mathrm{M})$, extract at various concentrations $(0-1.0$ $\mathrm{mg} / \mathrm{mL})$ and PMS $(2.7 \mu \mathrm{M})$. All reagents and extract were dissolved in $19 \mathrm{mM}$ phosphate buffer, $\mathrm{pH}$ 7.4.

\subsubsection{Hydroxyl radical (HO') scavenging assay}

The $\mathrm{HO}$ scavenging activity was measured by monitoring the $\mathrm{HO}$-inducing oxidation of luminol (Oosthuizen and Greyling, 2001) with modifications. $\mathrm{HO}$ was generated by a Fenton system $\left(\mathrm{FeCl}_{2} / \mathrm{EDTA} / \mathrm{H}_{2} \mathrm{O}_{2}\right)$. Reaction mixtures wells contained, in a final volume of $250 \mu \mathrm{L}$, the following reagents at the indicated final concentrations: $0.5 \mathrm{M} \mathrm{Na}_{2} \mathrm{CO}_{3}$ buffer, $\mathrm{pH} 10$, luminol $(20 \mu \mathrm{M}), \mathrm{FeCl}_{2}$-EDTA $(25 \mu \mathrm{M}, 100 \mu \mathrm{M})$, extract at various concentrations $(0-2.0 \mathrm{mg} / \mathrm{mL})$ and $\mathrm{H} 2 \mathrm{O} 2(3.5 \mathrm{mM})$. The iron salt was premixed with the chelator dissolved in water before addition to the reaction mixture.

\subsubsection{Hypochlorous acid (HOCl) scavenging assay}

The $\mathrm{HOCl}$ scavenging activity was measured by monitoring the $\mathrm{HOCl}$-inducing oxidation of luminol, accordingly to a described procedure (Yildiz et al., 1998) with modifications. HOCl was prepared immediately before use by adjusting the $\mathrm{pH}$ of a $1 \%(\mathrm{v} / \mathrm{v})$ solution of $\mathrm{NaOCl}$ to 6.2 with diluted sulphuric acid. The concentration of $\mathrm{HOCl}$ was further determined spectrophotometrically at $235 \mathrm{~nm}$ using the molar absorption coefficient of $100 \mathrm{M}^{-1} \mathrm{~cm}^{-1}$ (Aruoma, 1997). Reaction mixtures in the samples wells contained, in a final volume of $250 \mu \mathrm{L}$, the following reagents at the indicated final concentrations: $50 \mathrm{mM} \mathrm{Na} \mathrm{HPO}_{4}$ buffer, $\mathrm{pH} 12$, luminol $(250 \mu \mathrm{M})$, extract at various concentrations $(0-400 \mu \mathrm{g} / \mathrm{mL})$, and $\operatorname{HOCl}(25 \mu \mathrm{M})$.

\subsubsection{Peroxyl radical (ROO) scavenging assay}

The ROO scavenging activity was measured by monitoring the decay in fluorescence due to the oxidation of fluorescein, accordingly to a described procedure known by oxygen radical absorbance capacity (ORAC) assay (Fernandes et al., 2004.). ROO was generated by thermo decomposition of $\alpha$ - $\alpha$-azodiisobutyramidine dihydrochloride (AAPH). Reaction mixtures in the samples wells contained, in a final volume of $200 \mu \mathrm{L}$, the following reagents dissolved in $75 \mathrm{mM}$ potassium phosphate buffer, $\mathrm{pH} 7.4$, at the indicated final concentrations: fluorescein $(61 \mathrm{nM})$, extract at various concentrations $(00.01 \mathrm{mg} / \mathrm{mL})$ and AAPH $(19 \mathrm{mM})$. The scavenging effects are expressed as the relative trolox equivalent ORAC value, which is calculated by the following equation, where AUC represents the area under curve:

Relative ORAC value $=[($ AUC sample - AUC blank $) /($ AUC trolox - AUC blank $)] \mathrm{x}($ mass of trolox/mass of flavonoid $)$

\subsection{5 $\quad \mathrm{H}_{2} \mathrm{O}_{2}$ scavenging assay}

The $\mathrm{H}_{2} \mathrm{O}_{2}$ scavenging activity was measured by monitoring the $\mathrm{H}_{2} \mathrm{O}_{2}$-induced oxidation of lucigenin, accordingly to described procedure (Costa et al., 2005). Reaction mixtures in the samples wells contained, in a final volume of $250 \mu \mathrm{L}$, the following reagents at the indicated final concentrations: $50 \mathrm{mM}$ Tris buffer, $\mathrm{pH} 7.4$, lucigenin $(3 \mathrm{mM})$, extract at various concentrations $(0-10.0 \mathrm{mg} / \mathrm{mL})$ and $\mathrm{H} 2 \mathrm{O} 2(2 \%)$. 


\subsubsection{Nitric oxide ('NO) scavenging assay}

The NO scavenging activity was measured by monitoring the NO- induced oxidation of non-fluorescent 4,5diaminofluorescein (DAF-2) to the fluorescent triazolofluorescein, accordingly to described method (Nagata et al., 1999) with modifications. NO was generated by the 3-(aminopropyl-1-hydroxy-3-isopropyl-2-oxo-1-triazene (NOC-5). A stock solution of $2.07 \mathrm{mM}$ DAF-2 in DMSO was purged with nitrogen and stored at $-20{ }^{0} \mathrm{C}$. Working solutions of DAF-2 were

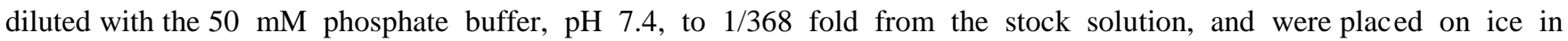
the dark immediately before the determinations. The reaction mixtures in the samples wells contained, in a final volume of $300 \mu \mathrm{L}$, the following reagents at the indicated final concentrations: DAF-2 $(5 \mu \mathrm{M})$, extract at various concentrations $(0-200 \mu \mathrm{g} / \mathrm{mL})$ and NOC-5 $(10 \mu \mathrm{M})$.

\subsubsection{Peroxynitrite $\left(\mathrm{ONOO}^{-}\right)$scavenging assay}

The $\mathrm{ONOO}^{-}$scavenging activity was measured by monitoring the $\mathrm{ONOO}^{-}$- induced oxidation of dihydrorhodamine 123 (DHR 123) to rhodamine 123, accordingly to described procedure (Kooy et al., 1994) with modifications. ONOO was synthesized as described before (Beckman et al., 1994). Prior to each study, the concentration of the stock peroxynitrite solution was determined spectrophotometrically in $0.1 \mathrm{M} \mathrm{NaOH}\left(\epsilon_{302 \mathrm{~nm}}=1670 \mathrm{M}^{-1} \mathrm{~cm}^{-1}\right)$. A stock solution of 2.89 $\mathrm{mM}$ DHR 123 in dimethylformamide was purged with nitrogen and stored at $-20{ }^{0} \mathrm{C}$. Working solution of DHR 123 diluted from the stock solution were placed on ice in the dark immediately before the determinations. The buffer ( 90 $\mathrm{mM}$ sodium chloride, $50 \mathrm{mM}$ sodium phosphate $(\mathrm{pH}=7.4)$ and $5 \mathrm{mM}$ potassium chloride) was purged with nitrogen and placed on ice before use. At the beginning of the experiments, $100 \mu \mathrm{M}$ DTPA was added to the buffer. Reaction mixtures in the samples wells contained, in a final volume of $300 \mu \mathrm{L}$, the following reagents at the indicated final concentrations: DHR $123(5 \mu \mathrm{M})$, extract at various concentrations $(0-200 \mu \mathrm{g} / \mathrm{mL})$ and $\mathrm{ONOO}^{-}(600 \mathrm{nM})$. In a parallel set of experiments the assays were performed in the presence of $25 \mathrm{mM} \mathrm{NaHCO}_{3}$.

\subsection{Enzymatic assays}

\subsubsection{Inhibition of xanthine oxidase (XO)}

Superoxide radicals were generated by the X/XO system following a described procedure (Fernandes et al., 1999). The reaction mixtures in the sample wells consisted of xanthine $(44 \mu \mathrm{M}), \mathrm{XO}(0.29$ unit/mL $)$, NBT (50 $\mu \mathrm{M})$, and sample $(5.2,10.4,20.8,41.7,83.3$, and $166.7 \mu \mathrm{g} / \mathrm{mL})$, in a final volume of $300 \mu \mathrm{L}$. Xanthine was dissolved in $1 \mu \mathrm{M}$ $\mathrm{NaOH}$, xanthine oxidase in $0.1 \mathrm{mM}$ EDTA, and the other components in $50 \mathrm{mM}$ phosphate buffer with $0.1 \mathrm{mM}$ EDTA, pH 7.8. Allopurinol (Standard) was dissolved in DMSO. The reaction was conducted at room temperature for 2 min and initiated by the addition of XO.

\subsubsection{Effect on XO activity}

The effect of the sample on XO activity was evaluated by measuring the formation of uric acid from xanthine in a doublebeam spectrophotometer (Shimadzu 2600), at room temperature. The reaction mixtures contained the same proportion of components as in the enzymatic assay for superoxide radical scavenging activity, except NBT, in a final volume of $600 \mu \mathrm{L}$. The absorbance was measured at $295 \mathrm{~nm}$ for $2 \mathrm{~min}$. Additionally, this procedure was repeated with several concentrations of xanthine $(11,22,44$ and $88 \mu \mathrm{M}$ and $73.2 \mu \mathrm{g} / \mathrm{mL}$ of sample, to get its inhibitory pattern.

\section{RESUlTS AND DISCUSSION}

The present results showed for the first time that gossypitrin exhibit scavenging activity against some ROS and RNS and the inhibition of xanthine oxidase (Table 1). The flavonoid presented a diverse capacity for scavenging all ROS and RNS tested as indicated by the corresponding $\mathrm{IC}_{50}$ values, include in Table 1 . All the reactive species were found at the $\mu \mathrm{g} / \mathrm{mL}$ range. $\mathrm{IC}_{50}$ for $\mathrm{O}_{2}{ }^{-}, \mathrm{HOCl}$ and $\mathrm{NO}$ were $28.9 \pm 3.2,1.17 \pm 0.19$ and $1.68 \pm 0.12 \mu \mathrm{M}$ of extract at various concentrations, respectively. No activity was detected in the $\mathrm{H}_{2} \mathrm{O}_{2}$ assay up to the sample concentration of $100 \mu \mathrm{M}$. The sample also showed a strong scavenging activity against $\mathrm{ONOO}^{-}\left(\mathrm{IC}_{50}=1.09 \pm 0.07 \mu \mathrm{M}\right)$, which was reduced in the presence of $\mathrm{NaHCO}_{3}$ $\left(\mathrm{IC}_{50}=2.12 \pm 0.15 \mu \mathrm{M}\right)$.

The ORAC value obtained was $2.68 \pm 0.22$, indicating an ineffective capacity for scavenging ROO species when compared to the trolox value (1). The scavenging activity of the sample towards DPPH at various concentrations $(0.015-$ $0.500 \mathrm{mg} / \mathrm{mL}$ ) was $18.376 \mu \mathrm{g} / \mathrm{mL}$, which was indicative of a weak activity against the radical at least twice, compared with quercetin $(8.052 \mu \mathrm{g} / \mathrm{mL})$, but it is acceptable because the international guideline recommended that a value under $20 \mu \mathrm{g} / \mathrm{mL}$ 
is considered to possess good antioxidant capacity. Reducing power assay of gossypitrin showed a value of $68.95 \mu \mathrm{g} / \mathrm{mL}$, indicating a weak capacity for decrease in absorbance compared with quercetin $(24.09 \mu \mathrm{g} / \mathrm{mL})$ used as standard. The TEAC value of gossypitrin was $2.14 \mathrm{mM}$ indicating two times lower activity against the radical cation $\mathrm{ABTS}^{\circ+}$, compared with quercetin $(4.56 \mathrm{mM})$.

TABLE 1

IC $_{50}$ VALUES CALCULATED FROM THE SCAVENGING ACTIVITY OF GOSSYPITRIN SAMPLE AGAINST DPPH, ABTS, REDUCING POWER, ROS, RNS AND ENZYMATIC ASSAYS

\begin{tabular}{|c|c|c|c|c|c|}
\hline No. & Assay & Method & \multicolumn{2}{|c|}{ Standard } & Gossypitrin \\
\hline 1 & DPPH & Biois, 1958 & Quercetin & $8,05 \mu \mathrm{g} / \mathrm{mL}$ & $18,376 \mu \mathrm{g} / \mathrm{mL}$ \\
\hline 2 & TEAC & Re y col., 1999 (m) & Quercetin & $4,56 \mathrm{mM}$ & $2,14 \mathrm{mM}$ \\
\hline 3 & Reducing Power & Oyaizu, 1986 & Quercetin & $24,09 \mu \mathrm{g} / \mathrm{mL}$ & $68,95 \mu \mathrm{g} / \mathrm{mL}$ \\
\hline 4 & $\mathrm{O}_{2}$ & Fernandes y cl., 2003 & Trolox & $1,83 \pm 0,09 \times 10^{3} \mu \mathrm{M}$ & $28,9 \pm 3,2 \mu \mathrm{M}$ \\
\hline 5 & HOCL & Yildiz y col., 2004 & Lipoic acid & $2,37 \pm 0,13 \mu \mathrm{M}$ & $1,17 \pm 0,19 \mu \mathrm{M}$ \\
\hline 6 & ROO & Fernandes y cl., 2004 & Fluorescein (Trolox) & 1 & $2,68 \pm 0,22 \mu \mathrm{M}$ \\
\hline 7 & NO & Nagata y col., 1999 & Rutin & $0,52 \pm 0,02 \mu \mathrm{M}$ & $1,68 \pm 0,12 \mu \mathrm{M}$ \\
\hline 8 & ONOO $(1 *)$ & Kooy y col., 1994 & Ebselen & $2,51 \pm 0,09 \mu \mathrm{M}$ & $1,09 \pm 0,07 \mu \mathrm{M}$ \\
\hline 9 & ONOO $(2 *)$ & Kooy y col., 1994 & Ebselen & $16,0 \pm 1,9 \mu \mathrm{M}$ & $2,12 \pm 0,15 \mu \mathrm{M}$ \\
\hline 10 & $\mathrm{H}_{2} \mathrm{O}_{2}$ & Costa y col., 2005 & Lucigenin & & $(*)$ \\
\hline 11 & $\mathrm{HO}$ & Oosthuizen y Greyling, 2001 & Luminol & & $(*)$ \\
\hline 12 & Inhibic. XO & Fernandes y cl., 1999 & Allopurinol & $5,11 \pm 0,19 \mu \mathrm{M}$ & $52,8 \pm 2,2 \mu \mathrm{M}$ \\
\hline
\end{tabular}

(*) No activity was detected in the $\mathrm{H}_{2} \mathrm{O}_{2}$ and $\mathrm{HO}$ assay up to the sample concentration of $100 \mathrm{mM}$. $\left(1^{*}\right.$ and $\left.2^{*}\right)$ within and without the presence of $\mathrm{NaHCO}_{3}$, respectively.

Enzymatic assay (Inhibition of xanthine oxidase) of various samples of gossypitrin (5.2, 10.4, 20.8, 41.7, 83.3, and 166.7 $\mu \mathrm{g} / \mathrm{mL})$ showed a value of $\mathrm{IC}_{50}(\mu \mathrm{M})=52.8 \pm 2.2$, which was indicative of weak activity compared with Allopurinol $(\mathrm{IC} 50=5.11 \pm 0.19 \mu \mathrm{M})$ used as standard (Table 1).

In vitro antioxidant methods results for the evaluation of antioxidant activities of gossypitrin isolated from the ethanolic extracts of the petals of $T$. elatum were expressed in the $\mathrm{IC}_{50}$ values i.e., the quantity of flavonoid needed to scavenge $50 \%$ of the radical produced in the reaction mixture. In addition, a chemical compound having low $\mathrm{IC}_{50}$ values is considered to possess strong antioxidant properties (Cuéllar \& González, 2009; González \& Cuéllar, 2010).

The role of ROS and RNS as the final common mediators of tissue damage in diseases of diverse etiologies emphasizes the wide range of therapeutic applications of antioxidants. The results demonstrated that this flavonoid exhibits an interesting antioxidant activity. It was able to quench DPPH radical, ABTS radicals and scavenge $\mathrm{HOCl}$ and ONOO: The TEAC value of gossypitrin allow include this chemical compound into the eleven better secondary metabolites in the nature (flavonoids, phenylpropanoid and carotenoids), according with the results of Rice-Evans and Miller, 1996.

\section{CONCLUSION}

On the basis of the results of the research, it is clear that gossypitrin have powerful antioxidant activity against various free radicals. The flavonoid showed antioxidant activity against all assayed radicals but with a different behavior in front of each tested radically specie. The results of the present investigation suggest, that the antasthmatic activity of the extracts of $T$. elatum used in Cuban traditional medicine, and recognized by the Ministry of Health (MINSAP), could be explained, at least in part, by their antioxidant and transition metal quelator properties. The bioguided isolation of the active constituents of $T$. elatum is being conducted, aiming the formulation of a safer and efficient drug. The ethanolic extracts from the petals of the flowers can be used as easily accessible source of natural antioxidants.

\section{CONFLICT OF INTEREST}

The authors declare no conflict of interest. 


\section{ACKNOWLEDGEMENTS}

The authors acknowledge REQUIMTE, Departamento de Química, Faculdade de Ciências e Tecnologia da Universidade Nova de Lisboa (Portugal) for experimental support for this work. Sincere thanks also to Mathew S, González T, Costa D, Segundo M A, Fernandes E. for their valuable assistance.

\section{REFERENCES}

[1] Larson, R. A. Phenolic and enolic antioxidants. Naturally Occurring Antioxidants. Boca Raton: CRC press LLC; 100-109, 1997.

[2] Akiyama, T.; Ishida, J.; Nakagawa, S.; Ogawa, H.; Watanabe, S.; Itoh, N.; Shibuya, M.; Fukami, Y. Genistein, a specific inhibitor of tyrosine-specific protein kinases. J. Biol. Chem. 262: 5592-5595, 1987.

[3] Wang, S.; De Groff, V. L.;Clinton, S. K. Tomato and soy polyphenols reduce insulin-like growth factor-I-stimulated rat prostate cancer cell proliferation and apoptotic resistance in vitro via inhibition of intracellular signaling pathways involving tyrosine kinase. J. Nutr. 133:2367-2376, 2003.

[4] Frey, R. S.; Singletary, K. W. Genistein activates p38 mitogen activated protein kinase, inactivates ERK1/ERK2 and decreases Cdc25C expression in immortalized human mammary epithelial cells. J. Nutr. 133: 226-231, 2003.

[5] Rowland, I.; Faughnan, M.; Hoey, L.; Wahala, K.; Williamson, G.; Cassidy, A. Bioavailability of phyto-oestrogens.Br. J. Nutr. 1: S45 - S58, 2003.

[6] Roig, J. T. Plantas Medicinales Aromáticas y Venenosas de Cuba. Editorial Científico Técnica, La Habana, 618-619, 1974.

[7] Acosta de la Luz, L. L.; Rodríguez Ferradá, C. A. Plantas medicinales. Bases para una producción sostenible. Agrinfor, Impresiones MINAG, 124-125, 2006.

[8] Blois MS. Antioxidant determination by the use of a stable free radical. Nature 181: 1199, 1958.

[9] Re R, Pellegrini N, Proteggente A, Pannala A, Yang M, Rice-Evans C. Antioxidant activity applying and improved ABTS radical cation decolorization assay. Free Radic Biol Med, 26: 1231, 1999.

[10] Oyaizu M. Studies on products of browing reaction prepared from glucosamine. Jpn J Nutr. 44: 307-314, 1986.

[11] Fernandes, E.,Toste S. A., Lima, J. L. F. C., Reis S. The metabolism of Sulindac enhances its scavenging activity against reactive oxygen and nitrogen species. Free Radical Biology and Medicine. 35, 1008-1017, 2003.

[12] Oosthuizen, M.M. J., Greyling, D. 2001. Hydroxyl radical generation: The effect of bicarbonate, dioxygen and buffer concentration on pH-dependent chemiluminiscence. Redox Report. 6, 105-116, 2001.

[13] Yildiz, G., Demiryurek, A.T., Sahin-Erdemli, I., Kauzik, I. Comparison of antioxidant activities of aminoguanidine, methylguanidine by luminol-enhanced chemilumiscence. British Journal of Pharmacology. 124, 905-910, 1998.

[14] Aruoma, O.I. Scavenging of hypochlorous acid by carvedilol and ebselen in vitro. General Pharmacology. 28, 269-272, 1997.

[15] Fernandes, E., Costa D., Toste, S,A., Lima, J.F.C., Reis, S. In vitro scavenging activity for reactive oxygen and nitrogen species by nonsteroidal antiinflammatory indole, pyrrole, and oxazole derivative drugs. Free Radical Biology and Medicine, 37, 1895-1905, 2004.

[16] Costa, D., Gomes, A., Reis. S., Lima J. L. F. C, Fernandes, E. Hydrogen peroxide scavenging activity by non-steroidal antiinflamatory drugs. Life Sciences 76, 2841- 2848, 2005.

[17] Nagata, N., Mornose, K., Ishida, Y. Inhibitory effects of catecholamines and antioxidants on fluorescence reaction of 4,5diaminofluorescein, DAF-2, a novel indicator of nitric oxide. Journal of Biochemistry 125, 658-661, 1999.

[18] Kooy, N. W., Royall, J.A., Ischiropoulos, H., Beckman, J. Peroxynitrite-mediated oxidation of dihydrorhodamine 123. Free Radical Biology and Medicine 16, 149-156, 1994.

[19] Beckman, J.S., Chen, J., Ischiropoulas, H., Crow, J.P. Oxidative chemistry of peroxynitrite. Methods in Enzimology 223, 229-240, 1994.

[20] Fernandes, E., Borges, F., Milhazes, N., Carvalho, F.D., Bastos M.L. Evaluation of superoxide radical scavenging activity of gallic acid and its alkyl esters using an enzymatic an non-enzymatic system. Toxicol. Lett. 109, 42, 1999.

[21] Cuéllar Cuéllar, A., González Yaque, J. Biological activities of Gossypitrin isolated from the flowers of Talipariti elatum S.W. MBARARA University Medical Journal. Mbarara, Uganda. Volume 15. Pages 14-17. January 2009.

[22] González Yaque, J.; Cuéllar Cuéllar, A., Biological activities of Gossypitrin isolated from the flowers of Talipariti elatum S.W. NCSI Magazine. Biological Sciencies. Special Edition 2010. Volume 41, 2010. ISSN: 0253-568.

[23] Rice-Evans CA and Miller NJ. Antioxidants activities of flavonoids as bioactive components of food. Biochemical Society Transactions. Vol 24. 790-795, 1996. 